\title{
Edification Dictums in the Language Consciousness of the Kazakh Ethnos
}

\section{Паремии-назидания в языковом сознании \\ казахского этноса}

Galina Abramova ${ }^{1}$

Ph.D. in Linguistics, Assistant Professor
Галина Абрамова ${ }^{1}$

кандидат филологических наук, доцент

\section{E-mail: nishgalina@mail.ru \\ https://orcid.org/0000-0001-7105-918X}

\section{Natalya Dmitryuk ${ }^{1,2}$ \\ Dr. Sc. in Philology, \\ Professor}

Наталья Дмитрюк ${ }^{1,2}$

доктор филологических наук, профессор

E-mail: nvdmitr@yandex.ru https://orcid.org/0000-0002-8527-0338

${ }^{1}$ South-Kazakhstan

State Pedagogical

University

13, Bajtursynov Str., Shymkent,

Kazakhstan, 160012

${ }^{2}$ South Ural

State University

$\bowtie 76$, Lenin Str.,

Chelyabinsk, 454080
${ }^{1}$ Южно-Казахстанский государственный педагогический университет

$\triangle$ ул. Байтурсынова, 13, Шымкент, Казахстан, 160012

${ }^{2}$ Южно-Уральский государственный университет

$\triangle$ ул. Ленина, 76,

Челябинск, 454080

Original manuscript received March, 01, 2020

Revised manuscript accepted October, 07, 2020 
Edification Dictums in the Language Consciousness of the Kazakh...

\section{ABSTRACT}

Introduction. Objective: linguacultural analysis of the edification words collected in a free associative experiment (FAE) and published in the "Kazakh Associative Dictionary». Materials \& Methods. Set of associations of instructive character singled out by the continuous sampling method into a separate fragment of the world paremiological image is a unique representative research material included into the Kazakh Associative Dictionary, in the 23655 associative reactions of the students of different universities in Shymkent city for112 stimulus words, 272 sayings - edifications recorded in 200 questionnaires. Archetypal layers of the ethnic linguistic consciousness represented in the edifying paremias reflect the Kazakh spiritual and moral values. The content of the FAE and Kazakh Associative Dictionary reflects the indicative feature of the study, i.e. introduction of the gender factor differentiating the men and women associations; it provided for revealing and presentation of the reliable characteristics of the gender determined linguistic consciousness of the informants. The content of the sayingsedification mainly relates to the moral life of the nation, they enshrine the generally accepted ethical norms.

Results. Gender irrelevant positions: evil and good are equally evaluated differently; respect for elders is clearly manifested.

Gender marked positions: for men - duty to the homeland, responsibility for the family; desire to work together; for women - the desire to protect family values, to correspond to the accepted world order, androcentrism.

Conclusions. The linguistic consciousness of the ethnos (in particular, its fragment as an actively demanded paremiological fund) reflects archetypal ideas about the ethnic spiritual and moral worldview values, on which stable elements of the modern Kazakh linguistic culture are formed and actively functioning; being vital for the ethnic integrity.

Key words: associative experiment, paremias, archetypes of consciousness, mentality, gender, ethno-cultural.

\section{Introduction}

Recently updated scientific researches in the field of ethno culturology, social psychology, ethno social psycholinguistics are necessarily to be treated particularly attentively and with an extreme responsibility in relation to the previously investigated research results (Goroshko, 2001, 2004; Dronjic \& Helms-Park, 2012). The logical and promising object of scientific research in recent years are the revival of national traditions (see Kent \& Rosanoff, 1910a, b; Mikołajczak-Matyja, 2015), the basic elements of culture, the reassessment of spiritual and mental values in the modern period of the construction of sovereign 
states, including Kazakhstan (see Abramova, 2019; Arynbayeva \& Dmitryuk, 2019; El-Dakhs, 2017; Giles \& Maass, 2017; Karimzad \& Catedral, 2018; Keblusek, Levesque \& de Moissac, 2018 etc.).

"The desire to preserve the identity and uniqueness of the language and culture is determined by the dialectical laws of the development of society and testifies to its vitality. Any ethnic group intuitively or consciously seeks to preserve that core, that linguistic and cultural dominant, which unites its representatives and at the same time separates them from the foreign cultural surrounding» (Dmitryuk, 2013: 104).

This idea of differences is highly stressed by MikołajczakMatyja (2015), Kheirzadeh and Hajiabed (2016), and El-Dakhs (2017) in functioning the speech of monolinguals and bilinguals and word associations of Arab learners of English as a Foreign Language.

Objective. The object area of our research is the linguistic consciousness of modern Kazakhstani society, in particular, representatives of the titular ethnic group of Kazakhstan; it was reflected in the materials of our mass free associative experiment (hereinafter FAE), on this material the Kazakh associative dictionary was based (Kazakh Association Dictionary (further - KAD-2014). It was the first scientific research considering the gender factor of association, i.e. male and female answers - associative reactions were fixed separately (Dmitryuk et al., 2014; Sharifian, 2017; Pauwels, 1998). The content of this dictionary turned out to be very promising and knowledge-intensive in the light of modern trends in the development of related humanities (ethnopsycholinguistics, mental linguisticsistics, linguoculturology etc.) to identify the national and cultural specifics of perception and understanding of the surrounding world, ethnically specific behavior stereotypes, basic human values and their hierarchy in the linguistic consciousness both of an individual and an ethnic group. Figurative meaning understanding is of great importance in connection to the free associative experiment (Kalmykova, Kharchenko \& Mysan, 2019, Kharchenko, 2015, 2017; Dronjic \& Helms-Park, 2012). Published papers of the researchers Dmitryuk, Moldaliyeva and Moldanova (2016), Mezentseva and Dmitryuk (2017), Lin, MacLeod and Colin (2018), Abramova (2019), Arynbayeva and Dmitryuk (2019), Balyasnikova and Dmitryuk (2020), Tarasov and Zhuravlev (2020), and others based on the material of this dictionary are actively investigating the issues on 
Edification Dictums in the Language Consciousness of the Kazakh...

linguistic consciousness and the linguistic world image, specifying the linguistic and cultural characteristics of the Kazakh ethnos mentality.

Research Questions. The following problem are discussed in this article:

(1) The functioning of the paremiological fund in the linguistic consciousness of the young generation in the Kazakh ethnic group and the degree of its actualization in their speech.

(2) Worldview position and mental «climate» of the young generation, manifested in the associative choice of utterances - edifications that reflect the archetypical ideas about the spiritual and moral values of the ethnic group.

(3) Gender characteristics of the respondents' associative response with instructive paremias.

(4) The values of preserving the moral foundations specific to the Kazakh ethnos, enclosed in the paremias of edification, being one of the basic elements ensuring the integrity and vitality of the ethnos.

Purpose of the Study. Purpose of the Study is to explore the actualization degree of specific paremies (proverbs) of edifying nature in the linguistic consciousness and in the speech of modern Kazakhstanis as they are considered to be the stable elements of modern Kazakh language culture, based on spiritual and moral worldview values that unite ethnos.

\section{Research Methods}

Free associative experiment (FAE). On the basis of the world wide accepted FAE method and the Associative Dictionary (KAD-2014) created on its material, we used the method of continuous sampling for analytical studies of 200 questionnaires filled out by 100 young male and 100 female respondents. In the international practice of associative research, it is believed that such a number of informants are sufficient to obtain certain system data for identifying strategies for associative behavior and structuring language consciousness, for collecting information on the commonality and specificity of gender, age, social, and other features of lexical association.

According to Balyasnikova and Dmitryuk (2020), Ufintseva (2020), Ufintseva and Balyasnikova (2019), and Balyasnikova et al. 
(2018) the data of mass associative experiments reflect the real state of everyday consciousness of a speaker / bearer of a certain language / culture. The list of verbal stimuli for conducting FAE was provided by a list of 112 words compiled in the Russian Academy of Sciences Linguistics Institute Department of Psycholinguistics and Theory of Communication (Moscow); the list has been widely tested in research practice (Ufimtseva, 2000: 218). The Dictionary continues to follow the main principles of the previous publications concerning the associative dictionaries (Karaulov et al., 2002).

\section{Research Material}

As a material for the study, we chose a fragment of the paremiological image of the world, representing words and sayings of an edifying character. While processing the results of the experiment we found a very significant in number word-group of the particularly edifying character in the entire bulk of associative answers, excepting for proverbs and sayings. We included sayings-prohibitions, sayingsinstructions and teachings, sayings-well-wishes, conditionally singled out into a separate group according to the lexical-semantic and grammatical principles: they differ from proverbs, firstly, with the vividly figurative moral content and educational goal setting and, secondly, grammatically they are expressed in the form of an infinitive (for example, Адам болу; Аман болу; ('Be human'; 'Be healthy') or imperative (Досты macman кетпе - 'Do not leave your friend'; Әлсіздерді құнама - 'Do not offend a weak person'; Жамандық жасама - 'Do no harm to anyone'), or in the form of affirmation or denial, often with a modal meaning of the desirability or undesirability of an action (Әдемі өмір сүру керек 'You have to live beautifully'; Ақұшава көп құызықпау керек - 'No need to be too interested in money'; Әдемі өмір сүру керек - 'Take care of the family' etc.). We extracted all lengthy answers from the entire body of the associative reactions to a given list of stimuli, (fragments of texts, stable clichéd expressions, proverbs, sayings, etc.) and systematized the material conditionally into three thematic groups:

(a) proverbs and sayings of the Kazakh language (143 proverbs in 399 answers);

(b) sayings-edifications and well-wishes (102 sayings in 272 answers); 
Edification Dictums in the Language Consciousness of the Kazakh...

(c) phraseologically stable expressions of the Kazakh language (165 phraseological units in 736 answers).

Totally, 1407 associative answers were extracted from the selected fragment as the research material of the study.

\section{Results}

\subsection{Gender aspect in the content of sayings-edifications in the experimental materials}

Almost all sayings - edifications, regardless of the number of words that compose them, are used in an indefinite form - in the infinitive (болу meaning 'to be' and the like) or in the imperative verb form - in the imperative (бол meaning 'be' and so on). This infinitive and imperative grammatical assignment of the form in sayings-edifications determines their content in general: such statements represent instructions, wishes, advice, or, on the contrary, prohibitions of a moral and ethical character; and, like proverbs and sayings, they reflect the quintessence of folk wisdom (Dmiryuk, Baigutova \& Mezentseva, 2015).

Due to the limited publication volume and the inappropriate placement of multi-page tables, we shall outline only the main approaches to the analysis of the obtained material and dwell on the gender features of the functioning of Kazakh sayings-edifications in the speech practice (and therefore in the linguistic consciousness) of male and female - representatives of the titular ethnic group of Kazakhstan.

We selected the Kaydar (2003) traditional classification of clichéd elements according to their quantitative composition to structure the sayings of edification. So, 101 sayings of the edifying character were recorded in the associative experiment (42 two-word, 44 three-word and 15 verbose) from 272 respondents (from 133 men and 139 women more than 200, as some respondents used two-three associations for their answers).

Judging by the summarized data, Kazakh men and women use the paremias of edification noted in the FAE materials approximately equally in their speech; it does not meet the idea of the masculine preferred laconicism and the tendency of women to more «spacious» forms of expression that are intuitively present in the consciousness of the ethnic group. 
Let us have a look at the content of paremias recorded in the associative fields of various stimuli, preferably used by men and women. It should be noted that during FAE, men more often respond to stimulus words бала (boy, child), бірге (together), жамандық (evil), жаман (bad, bad man), Отан (homeland), ОТБАСЫ (family)*.

Men and women equally manifested their attitude towards good and evil, although it is interesting to note the grammatical form of edification that they preferred: men often express this with a prohibitive, negative construction (Жамандық жасама, Жаман іске барма 'do no evil'), and women - use affirmative construction (Жақссыльық қ̧айтады, Жақ̧сылықық жасау - 'do good things').

\subsection{Sayings-Edifications Used by Men}

Considering the content of the sayings-teachings most frequently used by men (see Table 1), we can see that the core moral concepts for a Kazakh man are ideas about their duty to the Motherland, which must be defended (8), before the family, which must be protected and loved (7), and certain attitudes toward a communality, the success of joint efforts as a manifestation of a certain life position (Бәріміз бірге 'all together, the whole world' - 11), as well as the rejection of evil, prohibition on evil actions and deeds (15 answers).

Table 1. High Frequency Sayings - Edifications Used by Men

\begin{tabular}{|c|c|c|c|c|c|}
\hline \multirow[t]{2}{*}{ № } & \multirow[t]{2}{*}{ Stimulus word } & \multirow[t]{2}{*}{ Sayings - Edifications } & \multicolumn{3}{|c|}{$\begin{array}{c}\text { Frequency of } \\
\text { occurrence }\end{array}$} \\
\hline & & & total & men & women \\
\hline 1. & Бала (bоy) & $\begin{array}{l}\text { 1. Бала - ана бақыты (Child - mother's } \\
\text { happiness) }\end{array}$ & 5 & 4 & 1 \\
\hline 2. & Бірге (together) & 1. Бәріміз бірге (All together) & 11 & 11 & - \\
\hline 3. & Жамандық (evil) & 1. Жамандық жасама (Don’t do any harm) & 14 & 12 & 2 \\
\hline 4. & Жаман (bad) & 1. Жаман іске барма (Do not go to a bad deed) & 4 & 3 & 1 \\
\hline 5. & От (flame) & $\begin{array}{l}\text { 1. Отпен ойнауға болмайды (You cannot play } \\
\text { with fire) }\end{array}$ & 4 & 3 & 1 \\
\hline 6. & Отан (Motherland) & 1. Отанды қорғау (Defend Motherland) & 8 & 8 & - \\
\hline \multirow{3}{*}{7.} & & 1. Отбасынды сақта (Take care of your family) & 4 & 4 & - \\
\hline & Uтоасы (family) & 2. Отбасыңды сүй (Love your family) & 3 & 3 & - \\
\hline & & Total: & 53 & 48 & 5 \\
\hline
\end{tabular}

* Hereinafter, we will designate the stimulus word in capital letters, and associative responses in italics, as is customary in most works related to the analysis of experimental material obtained in the course of various associative experiments. 
The body of associative answers-sayings of an edifying nature that we have collected allows us to state the following.

Young men (our respondents were mainly students of various specialties) strive to 'live well', while, as many of them think, money is 'not the main thing: Әдемі өмір сүру керек ('You have to live beautifully'); Ақ̧шава көn қ̧ызықппау керек ('Do not value money too high'); Басты біліммен толтыр ('Fill your head with knowledge'); Өмірде өз жольн іздеу керек ('We must look for our own way of life'); Із қ̧алдыру ('...leave a trace in your life'); Ата-ананың Үмітін aķmay ('...to meet the expectations of one's parents'); Ақ̧ылдbl өз ойымен сүруді ('A clever man lives using his own mind') etc.

Young men, participants in the experiment reveal patriotic, high civic feelings, love for the motherland naturally and genuinely sincerely, without falsehood and carnival rethinking of the popular sayings on this topic. A very high and painful sensitivity threshold should be noted with the young Kazakhs, they reveal it when discussing the topical issues of the State structure, its sovereignty, language policy, and manifestation of a civic position on the crisis in the Ukraine, their relation to the Great Patriotic War. The young people are unambiguously patriotic and steady in the belief what the worth of our Victory was. Therefore, the proverbs and edification words about the duty to the Motherland and to the nation noted in the questionnaire are not vain words: Отанды қ̧орғау ('defend the Motherland'); Отан үшін өлуге дайьн ('Ready to die defending the Motherland'); Елім аман болсын ('May my people live'); Қазақ - бақылтmы хальқ ('Kazakhs are happy people') and others. Judging by other sayings used in the experiment, men are well aware of their duty to the family: Отбасыңды сақта ('Take care of the family'); Отбасыцды сүй ('Love your family') etc. At the same time, young men are quite well aware of the moral and ethical side of their deeds, realizing what should and what should not be done: Шындықъть айmy ('...tell the truth'); Бәріміз бірге болу ('...be all together'); Бнтыммақты болу ('...to be united'); Бір сөзде тұру ('...stand one's ground') and others.

A rather large number of answers are noted in the form of a negative imperative. They warn: Дocmbl macman кеmne ('Do not leave a friend'); Әлсіздерді құнама ('Do not scoff at the weak people'); Жамандық жасама ('Do not do bad things'); Сараң болмаңдар ('Don't be greedy'); Басқ̧аның ісіне араласпа ('Do not interfere into 
the other people's affairs'); Жаман іске барма ('Do not get involved into a bad affair') etc.

\subsection{Sayings-Edifications Used by Women}

Young Kazakh women, of course, are also quite well aware of the basic life values, foundations and traditions, and the Kazakh feminine patterns of behavior, which are stipulated by the fairly stable moral and ethical norms and laws adopted in the modern environment. The questionnaires of women participating in our experiment, are often marked with the associative answers of a warning type related to the arrangement of the generally accepted world order: Әлсіз болма ('Don't be weak'); Біреуді алдама ('Do not deceive anyone'); Жаман адам болма ('Do not be a bad person'); Нанды баспа ('Do not step on bread'); Отк̧а жолама ('Do not approach the fire') etc.

According to Table 2, such the stimulus words as ӘЛСІЗ (weak), ЕРКЕК (male), ЖАҚСЫЛЫҚ (kindly), ЖАМАН (bad, bad man), OPMAH (forest), ӨТIPIК (deception), and COҒЫС (war) turned out to be more 'in demand' for associative response among women (48 out of 70 respondents). The edict-editions reflected in Table 2, used mostly in the speech of female Kazakhs, primarily express respect for the man, it is also an effective educational factor for young children (Әлсіз болма - 'Do not be weak', Еркек болу керек - 'You need to be a man'); and just as men, the women expressed their negative attitude towards the war, it was noted in the associative field of the СОҒЫС stimulus (Совыс болмасын - 'No war!').

Table 2. High Frequency Sayings - Edifications Used by Women

\begin{tabular}{|c|c|c|c|c|c|}
\hline \multirow[t]{2}{*}{ № } & \multirow[t]{2}{*}{ Stimulus word } & \multirow[t]{2}{*}{ Sayings - Edifications } & \multicolumn{3}{|c|}{$\begin{array}{l}\text { Frequency of } \\
\text { occurrence }\end{array}$} \\
\hline & & & total & men & women \\
\hline 1. & Әлсіз (weak) & 1. Әлсіз болма (Don’t be weak) & 8 & 2 & 6 \\
\hline \multirow[t]{2}{*}{2.} & Еркек (man) & $\begin{array}{l}\text { 1. Еркек екі сөйлемейді (Men do not say } \\
\text { anything twice) }\end{array}$ & 4 & - & $\begin{array}{l}4 \\
-\end{array}$ \\
\hline & & 2. Еркек болу керек (You should be a man) & 7 & 1 & 6 \\
\hline \multirow[t]{2}{*}{3.} & Жақсылық & 1. Жақсылық қайтады (Welcome back) & 4 & 1 & 3 \\
\hline & (good) & 2. Жақсылық жасау (To do good) & 4 & 1 & 3 \\
\hline 4. & $\begin{array}{l}\text { Жаман (bad, a } \\
\text { bad man) }\end{array}$ & 1. Жаман адам болма (Don’t be a bad man) & 9 & 3 & 6 \\
\hline 5. & Орман (forest) & $\begin{array}{l}\text { 1. Орманды келесі ұрпаққа сақта (Save the } \\
\text { forest for the next generation) }\end{array}$ & 5 & 2 & 3 \\
\hline
\end{tabular}


Edification Dictums in the Language Consciousness of the Kazakh...

\begin{tabular}{lllccc}
\hline 6. Өтірік (cheating) & 1. Өтірік айтуға болмайды (You can't cheat) & 6 & 2 & 4 \\
7. Соғыс (war) & 1. Соғыс болмасын (May there be no war) & 22 & 9 & 13 \\
& 2. Тыныштық керек (We need peace / silence) & 3 & 1 & 2 \\
\hline \multicolumn{2}{c}{ Total: } & 70 & 22 & 48 \\
\hline
\end{tabular}

We can mention a tendency in the informants' answers: if men tend to 'live well', women are more inclined to a fair world order, they tend to 'live with dignity: Арыңңның алдында жақ̧сыльљқ жасау ('Do a good deed in your morality’); Денсаульққтың қ̧адірін білу керек ('Health must be valued'); Адами қ̧асиетті жовалтпау ('Do not lose human characteristics'); Әділдік бәріне жарасады ('Justice makes everyone better'). We can also note a certain presence of the concept of androcentrism, when the male point of view prevails and male normative representations and life models are presented as uniform universal and social norms.

A particularly respectful attitude towards the seniors, parents, and women is an unconditional value in the Kazakh cultural traditions, and it can be traced in the associative answers of men and women equally: Ананы құрметте ('Respect Mother'); Жүзінен күлкі кетпесін ('Let the smile always be on the face'); Әйелді сақтау керек ('The woman must be protected'); Қыз балага қол көтерме ('Never beat a girl'); Қыз бала ұятты болуы керек ('The girl should be bashful'); Көшеде cyüicy ('Kissing on the street is a shame') etc.

\section{Discussions}

At the same time, we noted that in the associative field there are incentives of instructive sayings which are equally used by both men and women: Table 3 presents the examples of the associative answers in the form of sayings-edifications actualized in the materials of our FAE.

Table 3. The equivalent use of sayings

\begin{tabular}{lllccc}
\hline \multirow{2}{*}{ № } & \multicolumn{1}{c}{ Stimulus word } & \multicolumn{1}{c}{ Sayings of edification } & \multicolumn{2}{c}{$\begin{array}{c}\text { Frequency of } \\
\text { occurrence }\end{array}$} \\
\cline { 3 - 5 } & & \multicolumn{1}{c}{ total } & men women \\
\hline 1. Адам (man) & $\begin{array}{l}\text { 1. Адам болу (Be a man) } \\
\text { 2. Ақымақ (fool) }\end{array}$ & $\begin{array}{l}\text { 1. Ақымақ болмау керек (You shouldn't be } \\
\text { a fool) }\end{array}$ & 7 & 4 & 3 \\
3. Ақылсыз (stupid) & 1. Ақылсыз болмау (Not to be stupid) & 7 & 3 & 4 \\
\hline
\end{tabular}


Паремії-повчання в мовній свідомості казахського етносу

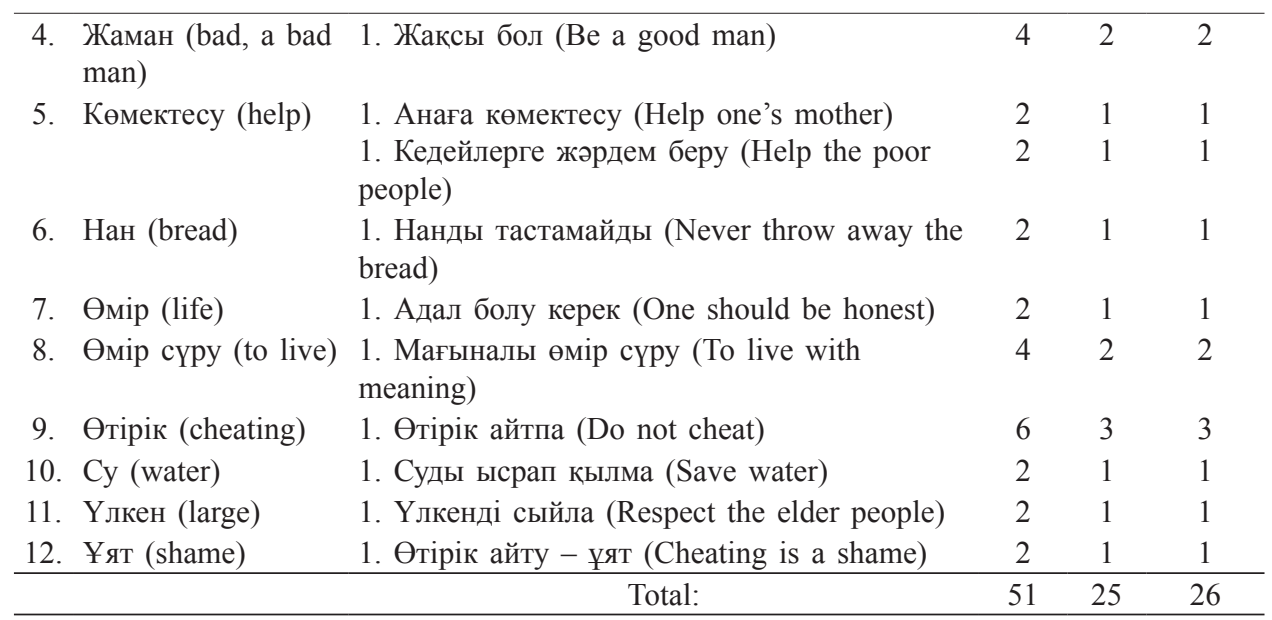

They testify to the simplest and most common universal rules and laws, tips and prohibitions with which one should live in any society, which are equally important for men and women, without differentiating between genders, age, ethnic differences, as these are the basic elements of the universal values on which any human community is to exist, to be saved, to be preserved, and function.

And still another specific feature of the Kazakh national cultural tradition, fixed in speech practice by the life principles of the archetypical consciousness of the nomadic people, - this is the deeprooted tradition of incredible hospitality, which is lacking in the modern Kazakhstani civilized society (often in the north-western regions), but in the southern regions of Kazakhstan this tradition is still a characteristics of this and is generally accepted. In the materials of our experiment, this characteristics is reflected quite clearly in the answers of both men and women which are presented in proverbs and edification words in the associative field of the ҚОНАҚ (GUEST) stimulus: Қонақ келсе құт болады $4^{*}$ ('With the arrival of the guest well-being comes'), Қонақұты күліп құарсы ал 3 ('Meet the guest with a smile'), Қонақ әкеңнен ұльг 2 ('A guest is more honorable than one's father'), Қонақ келсе алдына барыңды қой 2 ('If the guest has arrived, set the table'), Қонақ келсе қой егіз табады 1 ('With the arrival of the guests, a sheep gives birth to the two lambs instead of one'), Қонақты қ̧азақ халқы Құдайдай сыйлайды 1 ('Kazakh respect their guests as they

* The digits indicate the number of respondents responding with this association. 
respect God') and others (here, the numbers after the proverb mean how many times it is met in the profiles of informants). In the southern regions, until now, the Kazakhs when they are meeting guests, set the table abundantly; an improperly set, half-empty table is considered a shame, insufficient attention to guests is disrespectful; the arrival of guests without warning and in any quantity is the norm. Among the guests relatives on the part of the husband and wife, the owners of the house are most often numerous and this feature of corporate kinship among the Kazakhs is rooted in the traditions of mutual assistance and support of each other by the people of the same clan and tribe.

These specific, mentally and ethnically marked features of linguistic consciousness, characteristic of the titular ethnic group of Kazakhstan, are, in our opinion, a kind of reflection of the nomadic people archetypical way of life, they represent the unique features of unshakable moral and ethical values developed by centuries, on the basis of which the modern society is summoned to exist and function.

\section{Conclusions}

So, summing up the description of a fragment of the world paremiological picture, consisting of edifying words and sayings, extracted from the materials of the FAE, it should be noted that the data obtained and described by us are quite convincing and representative; undoubtedly, they reflect the archetypes of the linguistic consciousness of the Kazakh ethnos, which (the archetypes) at the same time, are indicative of the stable elements of the modern Kazakh linguistic culture that actively function in the linguistic consciousness and speech practice of the Kazakhstan modern titular ethnic group.

The study of the content and the transformation of ethnic mental basic values which are structured in the ethnic language consciousness core in a certain hierarchical sequence as the most significant, is of great interest, especially in our epoch when a trend of substitution of traditional national values by various types of universal and other benefits of civilization is manifested.

The associative direction can become very promising in Kazakhstan's psycholinguistics, which will be associated, firstly, with the identification of the area of coincidence of associative reactions the determination of ethnic constants, a certain unchanging rod in 
the collective consciousness of an ethnic group over a certain period of time; secondly, with the fixation of a certain area of change - the transformation and reformation of the linguistic consciousness of the titular ethnic group of Kazakhstan in the post-Soviet, post-reform and modern periods, which, of course, is not only of linguistic interest, but is also associated with the study of a wide range of social, ethno cultural and political issues of our time.

\section{References}

Abramova, G.I. (2019). Reflection of the Concept of Objective Time in the Linguistic Consciousness of Different Ethnic Groups. Science and Life in Kazakhstan, 11(2), 254-258.

Arynbayeva, R.A, \& Dmitryuk, N.V. (2019). Etnomentalnye osobennosti yazykovogo soznaniya: Vostok-Evraziya-Zapad v prizme associativnyh issledovanij [Ethnic Features of Linguistic Consciousness: East-Eurasia-West in the Prism of Associative Research]. Proceedings from: II World Congress «East-West: Crossing Borders» (Japan, Kyoto, October, 2-6, 2016), (Part 1, pp. 439-445). Kyoto: Kyoto Sangyo University [in Russian].

Balyasnikova, O.V., \& Dmitryuk, N.V. (2020). On Studying Actual Language Consciousness in Social and Regional Perspectives. The European Proceedings of Social and Behavioural Sciences (EpSBS): Vol. LXXXVI. The X International Conference "Word, Utterance, Text: Cognitive, Pragmatic and Cultural Aspects» (Chelyabinsk, October 1-3, 2020), (pp. 69-73). Chelyabinsk: Chelyabinsk State University. https://doi.org/10.15405/epsbs(2357-1330).2020.8.1

Balyasnikova, O.V., Ufimtseva, N.V., Cherkasova, G.A., \& Chulkina, N.L. (2018). Lingvistika i kogniciya: regionalnye perspektivy [Language and Cognition: Regional Perspective]. Vestnik Rossiyskogo universiteta druzhby narodov. Seriya: Lingvistika - Russian Journal of Linguistics, 22(2), 232-250. https://doi. org/10.22363/2312-9182-2018-22-2-232-250

Dmitryuk, N.V. (2013). «Civilizacionnyj slom» kak etnokulturnyj fenomen v zhizni sociuma. [«Civilizational scrapping» as an ethno-cultural phenomenon in the life of society]. In N. Ufintseva, A. Stepanova, D. Makhovikov \& L. Zhukova (Eds.), The X Mezhdunarodnyj kongress po psiholingvistike ISAPL: «Problemy informacionnogo obshchestva $i$ prikladnaya psiholingvistika» The X International Congress on Psycholinguistics ISAPL «Problems of the Information society and applied psycholinguistics» (June 26-29.06.2013), (pp. 103-104). Moscow: RUDN - Institute of Lingguistics RAN - MIL [in Russian].

Dmitryuk, N.V., Baigutova, D.N., \& Mezentseva, E.S. (2015). Otrazhenie nravstvennyh cennostej kazahskogo etnosa v prizme svobodnogo associativnogo eksperimenta [Moral values of Kazakhs in free associative experiment]. Voprosy psiholingvistiki - Journal of Psycholinguistics, 1(23), 159-171 [in Russian].

Dmitryuk, N.V., Moldaliyeva, D.A., \& Moldanova, Zh.I. (2016). Kazahsko-russkij slovoobrazovatelnyj sinkretizm $\mathrm{v}$ rechevom soznanii kazahov [Kazakh-Russian Word-Formation Syncretism in the Speech Consciousness of the Kazakhs]. 
Edification Dictums in the Language Consciousness of the Kazakh...

Vestnik Rossijskogo universiteta druzhby narodov. Seriya: Voprosy obrazovaniya Bulletin of Russian University Peoples Friendship. Series: Education Issues, 5, 273-280 [in Kazakh - Russian].

Dmitryuk, N.V., Moldaliyeva, D.A., Abramova, G.I. et al. (2014). Kazahskij associativnyj slovar [Kazakh Associative Dictionary]. Almaty - Moscow: MediaLogoS [in Kazakh - Russian].

Dronjic, V., \& Helms-Park, R. (2012). Fixed-choice word-association tasks as second-language lexical tests: What native-speaker performance reveals about their potential weaknesses. Published online by Cambridge University Press: 14 August 2012. https://doi.org/10.1017/S014271641200029X

El-Dakhs, A.S.D. (2017). The Effect of Language Exposure and Word Characteristics on the Arab EFL Learners' Word Associations. Journal of Psycholinguistic Research, 46(4), 1033-1052. https://doi.org/10.1007/s10936-017-9477-z

Goroshko, E.I. (2001). Integrativnaya model svobodnogo associativnogo eksperimenta [Integrative model of free associative experiment]. Moscow-Kharkiv: «RA-Karavella» [in Russian].

Goroshko, E.I. (2004). Gendernye osobennosti russkoyazychnogo Interneta [Gender peculiarities of the Russian-speaking Internet]. Naukovi zapiski Luganskogo natsionalnogo universitetu - Scientific notes of the Luhansk National University, 5(3), 8-30 [in Russian].

Kalmykova, L., Kharchenko, N., \& Mysan, I. (2019). Understanding of the Figurative Meaning by Preschoolers: Theoretical and Empirical Research. Problem space of modern society: philosophical-communicative and pedagogical interpretations. (Part II, pp. 130-153). Warsaw: BMT Erida Sp. z o.o.

Karaulov, Yu.N., Cherkasova, G.A., Ufimtseva, N.V., Sorokin, Yu.A., \& Tarasov, Ye.F. (2002). Russkii Assotsiativnyi Slovar [Russian Associative Vocabulary]. (Vols. 1-2). Moscow: LLC Astrel Publishers; LLC AST Publishers [in Russian].

Karimzad, F., \& Catedral, L. (2018). 'No, we don't mix languages': Ideological power and the chronotopic organization of ethnolinguistic identities. Language in Society, 47(1), 89-113. https://doi.org/10.1017/S0047404517000781

Kaydar, A.T. (2003). Tysyacha metkih $i$ obraznyh vyrazhenij: kazahsko-russkij frazeologicheskij slovar $s$ etnolingvisticheskimi poyasneniyami [Thousand of Accurate and Figurative Expressions: Kazakh-Russian Phraseological Dictionary with Ethnolinguistic Explanations]. Almaty: Bilge [in Kazakh - Russian].

Keblusek, L., Giles, H., \& Maass, A. (2017). Communication and group life: How language and symbols shape intergroup relations. Group processes \& Intergroup relations, 20(5), 632-643. https://doi.org/10.1177/1368430217708864

Kent, G.H., \& Rosanoff, A.J. (1910a). A study of Association in Insanity. Association in Normal Subjects. American Journal of Insanity, 67(1), 37-96.

Kent, G.H., \& Rosanoff, A.J. (1910b). A study of Association in Insanity. Association in Normal Subjects. American Journal of Insanity, 67(2), 317-390.

Kharchenko, N.V. (2015). Preschoolers' Listening Comprehension Development in Conjunction with Their Cognitive Development: a Meta-Analysis of Previous Research. East European Journal of Psycholinguistics, 2(2), 81-89.

Kharchenko, N.V. (2017). Listening in the Paradigm of Activity Psycholinguistics. Science and Education a New Dimension, 25(147), 37-41.

Kheirzadeh, S., \& Hajiabed, M. (2016). Differential Language Functioning of Monolinguals and Bilinguals on Positive - Negative Emotional Expression. 
Journal of Psycholinguistic Research, 45, 55-69. https://doi.org/10.1007/s10936014-9326-2

Levesque, A., \& de Moissac, D. (2018). Identité ethnolinguistique, continuité cultuelle et santé mentale chez les jeunes Franco-Manitobains: Une analyse exploratoire. Minorités linguistiques et société, 9, 185-206. https://doi.org/10.7202/1043502ar

Lin, Olivia Y.-H., \& MacLeod, Colin M. (2018). The Acquisition of Simple Associations as Observed in Color-Word Contingency Learning. Journal of Experimental Psychology: Learning, Memory, and Cognition, 44(1), 99-106. https://doi.org/10.1037/xlm0000436

Mezentseva, E.S., \& Dmitryuk, N.V. (2017). Associativnye sopostavitelnye issledovaniya v Kazahstane: bazovye cennosti [Associative comparative studies in Kazakhstan: Basic Values]. Bulletin of South Kazakhstan State Pedagogical Institute, 3(13), 98-104 [in Kazakh - Russian].

Mikołajczak-Matyja, N. (2015). The associative structure of the mental lexicon: hierarchical semantic relations in the minds of blind and sighted language users. Psychology of Language and Communication, 19(1), 1-18. https://doi. org/10.1515/plc-2015-0001

Pauwels, A. (1998). Women Changing Language. London: Longman.

Sharifian, F. (2017). Cultural Linguistics and Linguistic Relativity. Language Sciences, 59, 83-92. https://doi.org/10.1016/j.langsci.2016.06.002

Tarasov, E.F., \& Zhuravlev, I.V. (Eds.). (2020). Soznanie. Yazyk. Mozg [Consciousness. Language. Brain]. Moscow: Institut yazykoznaniya RAN [in Russian].

Ufimtseva, N.V. (2000). Yazykovoe soznanie $i$ obraz mira slavyan [Linguistic Consciousness and the Image of the Slavic world]. URL: https://iling-ran.ru/ library/psylingva/sborniki/Book2000/html_204/4-2.html [in Russian].

Ufimtseva, N.V. (2020). Associative-Verbal Network as a Model of the Linguistics Picture of the World. Proceedings of the X International Conference "Word, Utterance, Text: Cognitive, Pragmatic and Cultural Aspects», (EpSBS). (Chelyabinsk, October 1-3, 2020), (pp. 1460-1465). Chelyabinsk: Chelyabinsk State University.

Ufimtseva, N.V., \& Balyasnikova, O.V. (2019). Yazykovaya kartina mira i associativnaya leksikografiya [Language Picture of the World and Associative Lexicography]. Vestnik Volgogradskogo gosudarstvennogo universiteta. Seriya 2: Yazykoznanie - Science Journal of Volgograd State University. Linguistics, 18(1), 6-22. https://doi.org/10.15688/jvolsu2.2019.1.1 [in Russian].

\section{АННОТАЦИЯ}

Вступление. Объект исследования - лингвокультурологический анализ назидательных слов, собранных авторами в ходе свободного ассоциативного эксперимента (САЭ), на материале которого был создан Казахский ассоциативный словарь.

материалы и методы. Совокупность ассоциаций поучительного характера, выделенных методом сплошной выборки в отдельный фрагмент паремиологического образа мира, представляет собой уникальный репрезентативный исследовательский материал: из 23655 ассоциативных реакций студентов разных вузов г. Шымкента на 112 стимулов в 200 анкетах 
Edification Dictums in the Language Consciousness of the Kazakh...

зафиксировано 272 высказывания-назидания. Представленные в назидательных паремиях архетипические пласты этнического языкового сознания отражают духовно-нравственные ценности казахов. Показательной особенностью исследования, отразившегося в САЭ и содержании Казахского ассоциативного словаря, является введение гендерного фактора, дифреренцирующего ассоциации мужчин и женщин, что позволило представить достоверную картину особенностей гендерно обусловленного языкового сознания информантов. Содержание изречений-назиданий в основном относится К нравственной жизни народа, в них закреплены общепринятые этические нормы.

Результаты. Гендерно нерелевантные позиции: добро и зло одинаково оценочно диффреренцированы; отчетливо проявляется уважение к старшим. Гендерно маркированные позиции: для мужчин - долг перед родиной, ответственность за семью, стремление работать сообща; для женщин стремление оберегать семейные ценности, соответствовать принятому мироустройству, андроцентризм.

Выводы. Языковое сознание этноса (в частности, его фрагмент - активно востребованный паремиологический фонд) отражает архетипические представления об этнических духовно-нравственных мировоззренческих ценностях, на которых формируются и активно функционируют устойчивые элементы современной казахской языковой культуры, жизненно важные для этнической целостности.

Ключевые слова: ассочиативный эксперимент, паремии, архетипы сознания, ментальность, гендерный, этнокультурный.

\section{Абрамова Галина \& Дмитрюк Наталія. Паремії-повчання в мовній свідомості казахського етносу}

\section{АНОТАЦІЯ}

Вступ. Об'єкт дослідження - лінгвокультурологічний аналіз повчальних слів, зібраних авторами в ході вільного асоціативного експерименту (BAE), на матеріалі якого було створено Казахський асоціативний словник.

Матеріали та методи. Сукупність асоціацій повчального характеру, виділених методом суцільної вибірки в окремий фрагмент пареміологічного образу світу, являє собою унікальний репрезентативний дослідницький матеріал: з 23655 асоціативних реакцій студентів різних вузів м. Шимкента на 112 стимулів у 200 анкетах заріксовано 272 висловлювання-повчання. Представлені у повчальних пареміях архетипічні пласти етнічної мовної свідомості відображають духовно-моральні цінності казахів. Показовою особливістю дослідження, відтвореного у ВАЕ й змісті Казахського асоціативного словника, $\epsilon$ уведення гендерного фрактора, котрий диференціює асоціачії чоловіків $i$ жінок, що дозволило представити достовірну картину особливостей гендерно зумовленої мовної свідомості інформантів. Зміст висловів-повчань в основному 
відноситься до морального життя народу, в них закріплені загальноприйняті етичні норми.

Результати. Гендерно нерелевантні позиції: добро і зло однаково оціночно диреренційовані; чітко проявляється повага до старших. Гендерно марковані позиції: для чоловіків - борг перед батьківщиною, відповідальність за сім'ю, прагнення працювати спільно; для жінок - прагнення оберігати сімейні цінності, відповідати прийнятому світоустрою, андроцентризму.

Висновки. Мовна свідомість етносу (зокрема, його фррагмент - активно затребуваний пареміологічний фонд) відображає архетипові уявлення про етнічні духовно-моральні світоглядні цінності, на яких формуються й активно функціонують стійкі елементи сучасної казахської мовної культури, життєво важливі для етнічної цілісності.

Ключові слова: асоціативний експеримент, паремії, архетипи свідомості, ментальність, гендерний, етнокультурний. 